Ib Bondebjerg \& Anker Gemzoe:

\title{
Arbejderlitteratur - proletarisk litteratur - socialistisk litteratur
}

\section{Historisk-teoretisk indledning}

Ifølge den litteraturhistoriske kildeforskning fødes begrebet arbejderlitteratur i det revolutionært urolige Frankrig gennem udgivelsen af antologien »Poésies Sociales des Ouvriers« fra 1843. Herfra vandrer det nogle årtier senere til Karl Marx fødeland Tyskland gennem en oversættelse af antologien under titlen »Die Arbeiterdichtung im Frankreich.« Begrebet og fænomenet opstår altså her i sin allertidligste fase samtidig med den industrielle arbejderklasse og den faglige og politiske bevægelses begyndende konstituering. I denne tidlige fase henviser det forholdsvis uproblematisk til en kampbetonet brugslitteratur - oftest sange - skrevet af arbejdere eller organisk tilknyttede intellektuelle, som en litteratur der blev brugt af bevægelsen og klassen som udtryk for kollektive behov og formål: altså en litteratur der var med til at udvikle en kulturel klasseidentitet. Det tidlige begreb om arbejderlitteratur henviser altså til en alternativ litterær produktion, der både var skrevet af folk fra klassen eller bevægelsen, som handlede om klassens og bevægelsens livsforhold, søgte at udtrykke dens ideologi og som blev tilegnet kollektivt af dem, den var skrevet for. En nærmere undersøgelse af denne tidlige arbejderlitteraturs litterære formsprog og billeder vil imidlertid også vise, at det ikke drejer sig om en litteratur, der springer nyfødt ud af intet, men om en litteratur der forarbejder og benytter eksisterende traditioner og udtryksformer. Både begrebet og den faktiske litteratur afspejler altså tidligt det dilemma en alternativ kulturel klassebevægelse står $i$, når den som behersket og undertrykt klasse forsøger at bryde igennem det kapitalistiske samfunds ideologiske og kulturelle hegemoni. Dette kulturelle og litterære dilemma udtrykker imidlertid ikke bare en negativ erfaring: det ville være sekterisk at forestille sig at arbejderlitteraturen og arbejderklassen i sit gennembrud skulle kunne udkrystallisere sig som en renset alternativ kultur. Det er 
langt mere frugtbart og historisk korrekt at se arbejderlitteraturens frembrud som et udtryk både for et traditionsbrud og en traditionsarv, hvor arbejderkulturen og arbejderlitteraturen under sin vej frem allierer sig med og indoptager progressive elementer fra det borgerlige samfunds forskellige kulturelle traditioner.

Dette forhold betyder også at begrebet arbejderlitteratur, såvel som den faktiske arbejderlitteratur ikke éngang for alle kan fastlægges normativt, men udvikles og forandres gennem en historisk proces, der i takt med de historiske forandringer i arbejderklassens samfundsmæssige livsforhold, bringer stadig nye aspekter og muligheder frem til overfladen. Det kan derfor ikke undre at begreber og forestillinger knyttet til arbejderlitteraturen er præget af en kompleks begrebsforvirring: på den ene side har begrebet været præget af den skarpe polemik der har været rettet mod det fra den mere traditionelle borgerlige æstetiks fortalere, en polemik som ikke mindst har været præget af modviljen mod overhovedet at blande klassemæssige og politiske kriterier ind $\mathrm{i}$ æstetikken - på den anden side afspejler kampen om den »korrekte« arbejderlitteratur, kampen mellem rivaliserende retninger $i$ arbejderbevægelsen og den socialistiske intelligens. Beretningen om begrebet arbejderlitteratur er således samtidig beretningen om arbejderklassens historiske udvikling og om den ideologiske og kulturelle klassekamp, der har været følgen af denne udvikling.

2.

Den skandinaviske arbejderlitteratur-tradition - som belyses punktvis i dette nummer - rummer således også sin særegne historie, der udspringer af et klassesamfund, hvor udviklingen ikke har været præget af hverken voldelige borgerlige eller proletariske revolutioner. Den politiske og kulturelle hovedstrøm har været båret af en bred, stærkt organiseret socialdemokratisk bevægelse, der allerede midt i 1930'erne gled ind i et nærmere forhold til de mere etablerede institutioner i det borgerlige samfund. Denne bevægelse har i vid udstrækning holdt mere spontane kulturelle arbejderorganiseringer nede og formået at trænge venstreradikale og kommunistiske strømninger tilbage. Til gen- 
gæld har indflydelsen fra de småborgerligt dominerede folkelige og demokratiske bevægelser og den radikale intelligens og naturalismen spillet en stor rolle.

Udviklingen i den skandinaviske arbejderlitteratur viser da heller ikke nogle voldsomme brud, men tegner en nogenlunde lige kurve, hvor bevægelsen går fra en forholdsvis amatørpræget brugslitteratur med direkte rod $i$ en særegen arbejderoffentlighed under udvikling og frem mod en stadig mere professionaliseret og differentieret litteratur, hvor brydningen mellem forfatterens direkte berøring med arbejderklassen og en mere fritsvævende arbejderforfatterrolle bliver stadig tydeligere. Begrebet arbejderlitteratur skifter under denne proces ham: fra at være et begreb der peger på en litteratur med helt utvetydig produktions- og konsumtionsmæssig sammenhæng med arbejderklassen, som ikke står i noget direkte forhold til det almene litterære marked, bliver begrebet en betegnelse for en forfatter med eller uden direkte rod $\mathrm{i}$ arbejderklassen, der forsøger at tematisere arbejderklassens erfaringer og frembære dens ideologi via den litterære institution.

Denne udvikling peger på den nyere arbejderlitteraturs konstante udfordring og dilemma: både at skulle legitimere sig og fungere $\mathrm{i}$ forhold til den klasse hvis erfaringer den forarbejder, og samtidig at skulle kvalificere og sælge sig i forhold til de herskende traditioner og strømninger via et formidlingssystem, som ikke uden videre er et udtryk for arbejderklassens kulturelle behov - men som så sandelig heller ikke bare kan fejes af vejen som borgerligt bras. Skal man holde fast ved den oprindelige historiske kerne i begrebet arbejderlitteratur, så må man imidlertid definere den snævert som den litteratur der produceres af arbejderklassens egne folk i direkte tilknytning til og som et udtryk for dens hverdagsliv og organisationer. Men samtidig må det - med henblik på den senere historiske udvikling - gøres klart, at denne primære definition er for snæver til at dække det man i historiens løb med rette må opfatte som afledt af denne primære arbejderlitteratur.

Man har i mange forsøg på definitioner af begrebet arbejderlitteratur, især siden 1970, set tendenser i retning af at fả begrebet til at rumme al den litteratur, som på en eller anden måde 
blev betragtet som relevant for en socialistisk kamp i bred forstand. Bag ved dette ligger en vis arbejderisme og tendens til at bruge begrebet som et normativt kvalitetsbegreb, men bestræbelsen ender nemt $i$ den absurde udvidelse af begrebet og $i$ en forestilling om arbejderlitteraturen som den eneste alternative, progressive litteratur: selve det at være arbejderforfatter eller skrive arbejderlitteratur bliver progressivt og socialistisk. Overfor denne tendens kan der være grund til at fastholde den snævre, primære betydning af begrebet arbejderlitteratur som en betegnelse for en litteratur af forfattere fra arbejderklassen, hvad enten de nu er født ind i den eller har udviklet sig ind i den, - en litteratur som i væsentlig grad tematisk og indholdsmæssigt beskæftiger sig med klassens livssammenhæng og som står i ideologisk berøring med den. En arbejder der skriver »knaldromaner« på bestilling i sin fritid er således ikke arbejderforfatter, og heller ikke en arbejder der udelukkende skriver litteratur om alt mulig andet end arbejderklassen. Men på den anden side er en arbejder, der skriver litteratur som også handler om andet end arbejdere ikke af den grund pludselig en borgerlig skribent. I forbindelse med vores begreb om arbejderlitteratur er det måske også væsentlig at fastslå, at det ikke rummer bestemte normative æstetiske krav: den dokumentariske eller realistiske stil er ikke nødvendigvis saliggørende som stilen, der er på dette område absolut ingen grund til at tage de firkantede kommissær-briller på.

Fastholder man denne på visse måder mere snævre definition af begrebet arbejderlitteratur - som dog netop rummer vide æstetiske rammer, men gør begrebet meningsfuldt og afgrænseligt og fastholder den kulturpolitiske vigtighed $\mathrm{i}$ at arbejderne selv bliver litterært produktive i et arbejdsdelt klassesamfund, så bliver det til gengæld lige så vigtigt at præcisere en række tilgrænsende begreber. Der findes jo også den type litteratur, som ikke er skrevet af arbejdere, men dog bringer sig i ideologisk berøring med arbejderklassen, hvor en socialistisk grundholdning evt. træder frem og hvori arbejderklassen kan spille en vigtig rolle. Man kunne kalde denne type litteratur for proletarisk littera$t u r$, idet vi dermed angiver at den ikke nødvendigvis er skrevet af en forfatter fra arbejderklassen, men af en forfatter fra andre klasser eller grupper, der i praksis søger en alliance med arbej- 
derklassen og derigennem får et proletarisk tilsnit, som også kommer til udtryk i de litterære tematiseringer. (Begrebet proletarisk er historisk belastet som et ekstra-revolutionært udtryk for en bestemt type arbejderklasse, her bruger vi det dog neutralt og deskriptivt: proletarisk = arbejderklasseorienteret ).

For nu at eksemplificere fra dette nummers bidrag: Ulrik Gräs og til dels Arne Herløv Petersen, som behandles i Gunhild Aggers artikel er ikke, som hun også selv bemærker, arbejderlitteratur i den primære betydning, men er netop en proletarisk litteratur, som kombinerer en arbejderklassesynsvinkel med en bredere socialistisk venstrefløjsorientering, hvor også mellemlagenes livssammenhæng indgår. Ivar Lo-Johansson, som omtales $\mathrm{i}$ både Lars Furulands og Ola Holmgrens artikler er derimod en klassisk og typisk arbejderforfatter, som i kraft af sin sociale baggrund kan trække hele klassens historie op indefra gennem brug af egne primære erfaringer.

Arbejderklassens befrielse er arbejderklassens eget værk - sagde Karl Marx - arbejderlitteraturen er også arbejderklassens eget værk, men den er ikke den eneste afgørende litteratur i en bredere socialistisk befrielsesstrategi: det fælles mål for arbejderlitteraturen og den proletariske litteratur må være en fri, ubunden socialistisk litteratur, som gennemlyser samfundet på tværs af de klasseskel og kønsskel, som det er den socialistiske befrielses mål at ophæve. Begrebet socialistisk litteratur er derfor ikke et begreb snævert knyttet til arbejderklassen, men en samlebetegnelse for en bred strøm af litteratur præget af en socialistisk ideologi, og hvori både arbejderforfattere, proletariske forfattere og forfattere fra mellemlag og borgerlige miljøer indgår. Af disse sidste kan, fra Danmark, nævnes navne som Ivan Malinovski, Marianne Larsen, Erik Knudsen, Jesper Jensen, Hans Jørgen Nielsen, Dea Trier Mørch, Inge Eriksen, Jette Drewsen, m.fl.

Bag ved genopdagelsen af arbejderlitteraturen i 70'erne kom der nok uheldigvis til at ligge en for abrupt afskrivning af store dele af den øvrige litteratur: litteraturbegrebet blev i visse miljøer arbejderistisk indsnævret. Men de mere positive sider af genopdagelsen var en utopi om afmystificering af kunsten og udbredelsen af litterær praksis i flere klasser og lag. Kunsten for og af alle, kunstens funktionssammenhænge var vigtige pointer, 
der ikke burde betyde en seen bort fra æstetiske kvalitetsforskelle: kollektiviseringen af kunsten behøver ikke ske på bekostning af den særegne individuelle evne, men denne făr netop dobbelt central funktion og bliver mere forståelig i det øjeblik den ikke blot er et individuelt, specialiseret anliggende.

3.

Der er ikke plads til i denne korte indledning at udfolde den skandinaviske arbejderlitteraturs righoldige historie, men nogle tendenser skal påpeges. Det er et karakteristisk træk ved den skandinaviske arbejderlitteratur, at den i sine tidligste faser vokser frem som en mere spontan, radikal kamplitteratur, der afspejler situationen for en udstødt, uintegreret klasse, som overhovedet først må tilkæmpe sig en social, politisk, demokratisk og menneskelig identitet. Litteraturen, og dvs. først og fremmest sangene, fremstiller en elendighedskultur, hvor arbejderen er et objekt for en grov undertrykkelse, men hvor der også udtrykkes et abstrakt, radikalt fremtidshåb. Det er 1870'ernes og 1880'ernes arbejderkultur, der her kommer til udtryk, men igennem denne kamplitteraturs udvikling op omkring århundredskiftet afspejles også den begyndende udvikling hen mod en mere organiseret og veletableret arbejderkultur, hvor mere stabile sociale og politiske lag i den faglærte del af arbejderklassen rykker i centrum. Fra omkring århundredskiftet sætter imidlertid også en række nye tendenser og strømninger i gang, som afspejler en bredere rekruttering til arbejderlitteraturen og betyder at en række nye lag og grupper afsætter individuelle forfattertyper. På den ene side betyder den stadig stærkere ophobning af arbejdere i storbyens slum og industri, at en lang række skribenter i begyndelsen af 1900-tallet begyndte at skrive moralske problemromaner om arbejderklassen - oftest ud fra en meget indskrænket ideologisk horisont, som mere afspejlede en småborgerlig bekymring end en socialistisk ideologi - en proletarisk litteratur mærket af småborgerlig ideologi. På den anden side betød skærpelsen af arbejderklassens forhold på landet og bevægelsen mod byerne, at en række skribenter med landlig baggrund trak landarbejderne og de små husmænd med ind i litteraturen. M. A. 
Nexø var i Skandinavien en af de få arbejderforfattere som i denne brydningsperiode formåede at skabe en egentlig arbejderlitteratur, der bearbejdede og rummede alle disse aspekter. Hans forfatterskab trækker både ældre traditioner og erfaringer med sig og formår samtidig at åbne sig mod den nye bølge af arbejderlitteratur, som brød igennem i mellemkrigstiden, som i alle de skandinaviske lande blev den klassiske gennembrudsperiode for arbejderlitteraturen.

I mellemkrigstiden var arbejderkulturen nået til et sådant politisk, socialt og oplysningsmæssigt niveau, at arbejderlitteraturen kunne bryde igennem $\mathrm{i}$ bølger, der afspejlede forskellige ideologiske strømninger og bearbejdede forskellige lags erfaringer. Selvbiografier, erindringer, brede samfundskritiske romaner, lyrik og teater blev taget $\mathrm{i}$ brug i et omfang som vi skal helt frem til 1970 'erne for at finde magen til. Samtidig kom arbejderkvinderne også i mellemkrigstiden afgørende med, således som vi ser det med udgivelsen af kvindelige arbejdererindringer i Danmark og Moa Martinsson i Sverige, og således som Beth Juncker også beskriver det i sin artikel om den norske forfatter Karen Sundt, hvis kvaler med det at være arbejderforfatter, kvinde og så oven $\mathrm{i}$ købet leverandør til kolportagesystemet illustrerer de særlige problemer for den kvindelige arbejderlitteratur, som er et særligt begreb med sin egen historie.

Efter mellemkrigstidens store gennembrudsperiode kom besættelsestiden og den kolde krigs periode til at betyde et større tilbageslag for arbejderlitteraturen, som nok blev skrevet og udgivet, men i nogen grad rykkede ud i en mere marginal og usynlig position. De senere års genopdagelse af arbejderlitteraturens tradition og dens fornyede offensive placering $\mathrm{i}$ kulturdebatten og den litterære produktion er således blot et signifikant udslag af den kulturelle klassekamp og den herskende kulturs tendens til at udgrænse arbejderklassen: det kræver et aktivt kulturarbejde, ikke mindst fra de intellektuelle, at sikre os mod den slags fornyede forglemmelser her i 80 'erne. Dette nummer af Kultur \& klasse er i al beskedenhed et bidrag til at fastholde den historiske hukommelse og fragte den gennem en krisetid, som måske rummer tendenser til tilbagetrækning i mindre klassebestemte astetiske positioner. 